\title{
Research on Teaching Team Construction and Excellent Teaching Team
}

\section{Formation}

\author{
Ying Wang \\ School Of Design Of JiangHan University, WuHan, HuBei, China
}

Keywords: Teaching Team, Construction Goals, Key Factors, Evaluation System

\begin{abstract}
Teaching team construction is an effective way to organize the grass-roots level teaching and to enhance the quality of education of colleges and universities. Forming an excellent teaching team needs explicit goal and some of the key factors such as choosing and employing persons using scientific methods, a harmonious team culture and a good external environment. What's more, it also needs a fair and just way of performance appraisal to promote the healthy development and efficient operation of the whole teaching team.
\end{abstract}

\section{Introduction}

In 2007, the Ministry of Education and Ministry of Finance launched "The Project of Teaching Quality and Teaching Reform of Colleges and Universities” jointly, putting the Teaching Team Construction as a key construction project to guarantee and improve the quality of teachers, teaching ability and the quality of teaching. The file put forward explicitly that colleges and universities should strengthen the teaching team building, select and build a number of teaching teams with high teaching quality and reasonable structure, promote the reformation and research of the teaching content and methods, facilitate the exchange of teaching experience, develop teaching resources, intensify the training of young teachers. Colleges and universities all implemented this project as an important task of the school development.

\section{The connotation of the Teaching Team}

The team model has got the great success in the field of enterprise management, which attracted the attention of many fields including educational world. There has been the following two points of view on the definition of the teaching team, one is that improving the quality of teaching and teaching effectiveness and promoting the teaching reform should be the most important task for the teaching team, which consists of some teachers with a common teaching reform target. Another view is that the teaching team is composed of some teachers with a common teaching goal and a clear division of responsibility to each other, whose knowledge skills complement each other.

In total, the teaching team is an organization with reasonable structure based on one advantage disciplines or teaching and research section, which consists of some teachers in similar or same disciplines from different faculties, carry out academic activities and develop educational resources frequently, strive to enhance the teaching level of young teachers, improve the quality of teaching and cultivate innovative talents.

Team work is essentially different from personal work and competition model, emphasizing cooperation and coordination among team members in the work. 


\section{The Construction of Teaching Teams}

The Team Cooperation. Traditional teaching put more emphasis on the professional level of teachers and teaching investment, but now focusing on the individual's ability in teaching only is far from enough. The overall level of education of colleges and universities depends more on the degree of cooperation and the overall strength of the teaching team. Therefore, we must create an excellent teaching team, and give full play to the collective strength.

There is no doubt that good cooperative mechanism of teaching team is the most powerful guarantee to the teaching quality of universities. Currently, the practical experience of teaching teams of universities shows shat the construction of good cooperative mechanism needs a strong cohesion team. The primary task of teaching in universities is to train people with healthy personality, followed with good skills. Teaching team should have a high degree of consensus on the teaching ideas and Training objectives, based on this, team members can work together to form a force in the same direction in teaching.

Construction of Talent. The construction of teaching teams should not only pay attention to the construction of the existing team and reasonable adjustments to the team structure, but also have a long-term planning to reserve the follow-up force and develop talent.

Training for talents in teams must have a clear objective and rational plan. Some excellent teaching teams pay great attention to the cultivation of talents, they develop reasonable goals and plans according to their status and characteristics.

The combination of teaching and research. Teaching and research system seem to be separated, but they are closely linked and influenced each other in fact. American scholar Naer Fu thinks that the growth of research will benefit the improvement of teaching quality, they are complementary relationship. In team construction, each teaching team should pay attention to introduce scientific research into classroom by various ways.

First of all, improving teaching with scientific research. In excellent teaching teams, teachers set up specialized courses and elective courses according to their research direction, transform research results into the teaching content effectively.

What's more, in the process of scientific research teachers' knowledge base will be greatly enriched and their professional quality will be improved immensely. Teachers could introduce their latest research achievements to the textbook and classroom, allowing students to acquire new knowledge understand the new situation of the disciplines and guide students into the forefront of academic research as soon as possible.

Teachers bring research projects into teaching, using published research papers as extracurricular reading material, which can be extremely effective to cultivate students' research awareness and innovation ability.

Secondly, carrying out rich lectures. By organizing a variety of lectures, internal and external experts could transform their research results into lively teaching content, broadening the horizons of students greatly and deepening students' understanding of professional issues.

Next, introducing part-time teachers. Part-time teachers come from different professions, institutions and research institutions, they have different occupations and professional background. The teaching team with part-time teachers would have extremely rich, diverse academic character, teaching styles and teaching methods.

\section{Construction of Excellent Teaching Team}

Unified target. A Common vision and performance goals can determine the tone and ambition 
of the teaching team, inspire passion and solidarity of the team. The establishment of teaching team of colleges and universities should have a clear goal of teaching construction and development.

The teaching team of colleges and universities should take cultivating high-quality and high-skilled talents for the mission, improve teaching quality and ability of social services, innovate education ideas and education concept, Promote the teaching reform, strengthen the cooperation of school and enterprise to improve the quality of talents.

Key factors. First of all, we should have leaders. The role of leaders is very obvious in the process of cultural formation. A good team leader should have a strong sense of professionalism and high sense of responsibility, sense of innovation, strong ability of organizational, good ability to mobilize the enthusiasm and initiative of members and communicate with the team members, mediate internal conflicts. He could create a harmonious and pleasant working atmosphere.

Secondly, we should have a harmonious team culture. Team is a normal group, which consists of a number of teachers with a common target, whose knowledge skills complement each other. Team members are interdependent, and they have a common behavioral goals. Therefore, having a harmonious team culture is very essential to the development of team.

Next, we should have a favorable external conditions. Survival and development of any team depends on certain material conditions including the office space and facilities, and daily operation expenditure. Not only discipline construction, curriculum reformation, textbook compilation and teaching methods reform, but also practical training, the construction of teaching teams of colleges and universities is inseparable from the protection of financial, material and equipment.

Teaching team construction needs not only cooperation with finance, logistics, training bases and other departments, but also the integration of different department, different disciplines and education resources.

Colleges and universities should pay attention to create a loose and harmonious working atmosphere in school to give full play to the enthusiasm and creativity of all kinds of talents, forming a good working environment in which everyone wants to make performance, respects for knowledge, recognizes difference and appreciates each other, and it is suitable for the growth of all kinds of talents, making teachers in teams achieve their goals.

The key to create a good environment in which talents are respected greatly is that the leaders of colleges and universities can improve administrative style and service attitude fundamentally, take people as the foremost really, take the growth and development of teachers as the foundation, focus management on providing services.

\section{Evaluation System}

Scientific and rational evaluation system is an effective way to mobilize the enthusiasm of the team, test construction achievements, enhance the core competitiveness of the team. It is an important safeguard to ensure the orderly operation of the team. Performance review is a goal management and a process management, it is a continuous and closed-loop management system, which consists of many aspects.

Performance review is also an improved management, focusing on the accumulation and analysis of information. It can boost performance feedback and improving effect, correct and enhance performance constantly through increasing performance communication and the frequency of performance evaluation.

Therefore, the establishment of scientific and multi-dimensional performance evaluation system is very necessary.

Evaluation content. In the aspect of evaluation content, first of all, colleges and universities 
should assess personal performance evaluation of teachers, secondly, assess the degree of the realization of team goals, and then, they should assess the contribution of individual teachers in the implementation of team performance, next, estimators should assess the team ability and the sense of competition and cooperation.

Evaluation method. In the aspect of evaluation method, it is necessary not only to pay attention to the appraisal of the authorities and colleagues, but also focus on the evaluation of students and enterprises.

Evaluation link. In the aspect of evaluation link, it is necessary not only to pay attention to the final evaluation results of the team construction, but also focus on periodic supervision and examination in the construction process.

Every aspect of team construction would be improved and the overall objective of it could be achieved successfully by regular inspections and evaluation.

\section{References}

[1] W.P.Pan. A Research on the Teaching Team Construction of Jiangxi Newly Established 4-year Universities[D], Nanchang: Nanchang University, 2012. (In Chinese)

[2] F.Luan. A Research on the Excellent Teaching Team Demonstration of Quality Project of Colleges and Universities[J], Journal of Heilongjiang College of Education, 2015(34). (In Chinese)

[3] L.X.Ren, D.M.Fan and J.Liu. Construction of Evaluation Standard of Excellent and Professional Teaching Team of Higher Vocational Schools[J], Journal of Lvliang University, 2011(1). (In Chinese)

[4] B.C.Hu and L.C.Zhou. Targets and Strategies of Excellent Teaching Team Construction of Higher Vocational Schools[J], Vocational and Technical Education, 2010(31). (In Chinese)

[5] Y.He. A Research on the Teaching Team Construction of Colleges and Universities[J], Journal of China Institute of Industrial Relations, 2012(26). (In Chinese)

[6] F.Luan. A Research on the Excellent Teaching Team Demonstration of Colleges and Universities[J], Heilongjiang Education(Higher Education Research \& Appraisal), 2014(8). (In Chinese)

[7] G.L.Chang. Thinking of Excellent Teaching Team Construction of Colleges and Universities in the Project of Undergraduate Teaching[J], Heilongjiang Education(Higher Education Research \& Appraisal), 2014(10). (In Chinese)

[8] Y.P.Xie. The Research on Teaching Team-Building in University[D], Changsha: Hunan Univesity, 2010. (In Chinese)

[9] S.J.Lu and H.Y.Zhang. A Research on the Construction of Teaching Team in the Quality Project of Colleges and Universities[J], Education Exploration, 2010(4). (In Chinese)

[10] C.H.Guo. The Institutional Environment Analysis and Countermeasure Research of Teaching Team Construction of Colleges and Universities[J], Higher Agricultural Education, 2010(5). (In Chinese) 